\title{
Breast Cancer Pathologic Regional Lymph Nodes TNM Finding v7
}

\author{
National Cancer Institute
}

\section{Source}

National Cancer Institute. Breast Cancer Pathologic Regional Lymph Nodes TNM Finding v7. NCl Thesaurus. Code C88348.

A pathologic finding about one or more characteristics of breast cancer, following the rules of the TNM AJCC V7 classification system as they pertain to staging of regional lymph nodes. The classification is based on axillary lymph node dissection with or without sentinel lymph node biopsy. (partially adapted from AJCC 7th Ed.) 